\title{
cDNA Cloning and mRNA Expression of Bovine GPR39
}

\author{
Ichiro YAMAMOTO ${ }^{1)}$, Nobuhiro KIMURA ${ }^{2)}$, Toshiro ARAI ${ }^{1)}$ and Minoru TANAKA ${ }^{2) *}$ \\ ${ }^{1)}$ Laboratory of Veterinary Biochemistry, School of Veterinary Medicine, Nippon Veterinary and Life Science University, Musashino, \\ Tokyo 180-8602 and ${ }^{2}$ Department of Animal Science, Faculty of Applied Life Science, Nippon Veterinary and Life Science University, \\ Musashino, Tokyo 180-8602, Japan
}

(Received 10 September 2008/Accepted 27 November 2008)

ABSTRACT. GPR39 is an orphan G protein-coupled receptor that is thought to be involved in gastrointestinal and metabolic function. In this study, we cloned bovine GPR39 cDNA that encoded 462 amino acids showing high sequence homology to other mammalian GPR39 proteins. Real-time PCR showed expression of GPR39 mRNA in the liver, kidney, abomasums, small intestine, colon, rectum and uterus, with the highest level in the abomasums. Significant promoter activity was observed within the $-2.3 \mathrm{~kb} 5$ '-upstream region of bovine GPR39 gene with human colon carcinoma-derived CACO-2 cells. These findings suggest that GPR39 may have important roles in gastrointestinal and metabolic functions in bovines as in other mammals.

KEY WORDS: bovine, cDNA, GPR39, promoter.

GPR39 and GPR38 were initially identified as members of the orphan $\mathrm{G}$ protein-coupled receptor, which is sequentially related the to $\mathrm{GH}$ secretagogue receptor (GHS-R) and neurotensin receptor $[12,7]$. GPR38 has been found to be the receptor for motilin [4], and recently, a 23-amino acid peptide named obestatin has been postulated to be a specific ligand of GPR39 [21]. Obestatin is considered to be generated by posttranslational cleavage of proghrelin and shows effects opposite to those of ghrelin, such as suppression of food intake, reduction of body weight gain and decrease of gastric emptying [21]. However, it has recently been reported that obestatin has no effect on the activation of GPR39, food intake or body weight gain [1, 5, 6, 10, 14, 16]. Therefore, obestatin is currently not considered a ligand for GPR39. GPR39 constitutively activates intracellular signaling through $\mathrm{G}$ protein pathways, resulting in increased inositol phosphate turnover and activation of the cAMP and serum response elements [7]. These GPR39-mediated signals are further simulated by zinc ion [7, 17, 20]; however, the specific endogenous ligand for GPR39 is not yet known.

GPR39 mRNA has been shown to be expressed in a wide range of tissues in humans, rats, mice and chickens, with relatively higher levels in the liver, kidney, pancreas and gastrointestinal (GI) tract [3, 12, 13, 19, 21]. In GPR39deficient mice, accelerated gastric emptying of a solid meal, body weight gain and high body fat composition have been observed, which suggests that GPR39 plays important roles in digestive and metabolic functions [13]. In mammals, ghrelin, a specific ligand for GHS-R, stimulates GI motility as well as GH secretion and food intake $[9,11,18]$. The motilin-GPR38 system is also involved in the motility of the GI tract $[4,15]$, although this ligand-receptor system has not been identified in rodent species. In cows, motilin and ghre-

\footnotetext{
* Correspondence to: Tanaka, M., Department of Animal Science, Faculty of Applied Life Science, Nippon Veterinary and Life Science University, Musashino, Tokyo 180-8602, Japan. e-mail : mitanaka@nvlu.ac.jp
}

lin have been identified by cDNA cloning [2, 8]; however, their receptors and GPR39 have not yet been identified. Herein, we report the cDNA sequence, tissue mRNA expression profile and results of promoter analysis of the bovine GPR39 gene.

The cDNA of bovine GPR39 was cloned by a PCR-based method. Total RNA was extracted from the duodenum (Funakoshi Tokyo, Japan) of a 2-year-old Holstein cow with TRIzol (Invitrogen, Carlsbad, CA, U.S.A.), and poly $\mathrm{A}^{+}$ RNA was prepared from the total RNA with Oligotex-dT Super (Takara, Shiga, Japan). A cDNA library was prepared from the poly $\mathrm{A}^{+}$RNA by using a Marathon cDNA amplification kit (Clontech Laboratories, Mountain View, CA, U.S.A.). The 5'- and 3'- ends of the cDNA were amplified by using antisense (primer 1) and sense (primer 2) primers designed from a putative bovine GPR39 cDNA sequence predicted from the cow genome sequence (GenBank accession number XM_589836). The full-ORF region of bovine GPR39 cDNA fragment was amplified with another pair of sense (primer 3) and antisense (primer 4) primers. The sequences and positions of the primers are indicated in Table 1. The complete sequence data of bovine GPR39 cDNA has been submitted to the DDBJ/EMBL/GenBank databases under accession number EU031892. The Bovine GPR39 cDNA consisted of 137 bp of the 5'-untranslated region (UTR), $1365 \mathrm{bp}$ of the coding region and $944 \mathrm{bp}$ of the 3'-UTR. The 5'-region sequence of the putative GPR39 cDNA sequence predicted from the cow genome differed from that of the cloned GPR39 cDNA and shoed no significant homology with those of other mammalian GPR39 cDNAs (data not shown). Therefore, the 5'-region sequence of the putative GPR39 cDNA is considered to have been incorrectly predicted. A computer-assisted search of the bovine GPR39 cDNA sequence in the cow genome (www.ncbi.nlm.nih. gov/BLAST) showed the presence of an approximately $17.8 \mathrm{~kb}$ intron between positions 994 and 995 in the GPR39 cDNA, which indicates that the bovine 
Table 1. Sequences and positions of the primers used for PCR

\begin{tabular}{llll}
\hline Primer & Sequence (5'-3') & Position & GenBank Accession No. \\
\hline Primer 1 & CTCCTTCTGCAGGTAGCCTTTCTTC & 391 to 367 & XM_589836 \\
Primer 2 & CTTTGTGGTCTACCTTGTGGTCCTG & 871 to 895 & XM_589836 \\
Primer 3 & TCATGGCTTCCCCAAGCCAC & 136 to 155 & EU031892 \\
Primer 4 & TCACACTTCGTGCTCCTGAAA & 1502 to 1482 & EU031892 \\
Primer 5 & TGCAGGTGCTTAGGAGGAGT & 874 to 893 & EU031892 \\
Primer 6 & AGGATCATGTATGCTCGGAAGT & 1111 to 1090 & EU031892 \\
Primer 7 & GTAACCCGTTGAACCCCATT & 326 to 345 & XR_027844 \\
Primer 8 & CCATCCAATCGGTAGTAGCG & 476 to 457 & XR_027844 \\
Primer 9 & ACGCGTCTTATGGCCTTGAGGGGAAG & -2323 to -2303 & NW_930904.1 \\
Primer 10 & CTCGAGAGCTCACCTGGAAAAAGCAA & -138 to -119 & NW_930904.1 \\
\hline
\end{tabular}

\begin{tabular}{|c|c|c|}
\hline \multirow{5}{*}{$\begin{array}{l}\text { bGPR39 } \\
\text { hGPR39 } \\
\text { mGPR39 } \\
\text { rGPR39 } \\
\text { cGPR39 }\end{array}$} & \multirow{2}{*}{\multicolumn{2}{|c|}{1 MASPSHPSRDCSQVIDHSHVPEFEVATWIKITLILVYLVIFVVGILGNSVTIRVTQVLQKKGYLOKEVTDHMVSLACSDILVFLIGMPME }} \\
\hline & & \\
\hline & 1 & 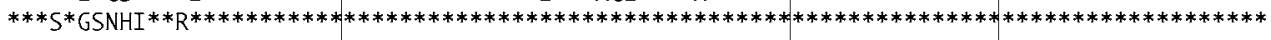 \\
\hline & 1 & 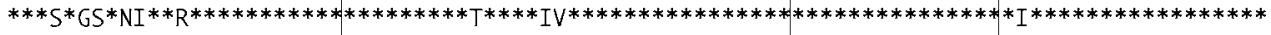 \\
\hline & 1 & 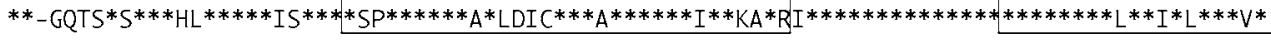 \\
\hline & & III \\
\hline SPR39 & 91 & FYSSIIWNPLTTPSYTVSCKVHTFLFEACSYATLLHVLTLSFERYIAICHPFRYKAMSGPCQVKLLIGFVWVTSALVALPLLFAMGVEYPL \\
\hline hGPR39 & 91 & 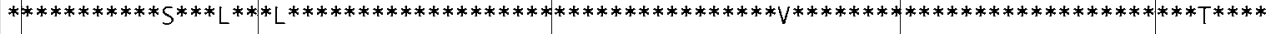 \\
\hline 39 & 91 & 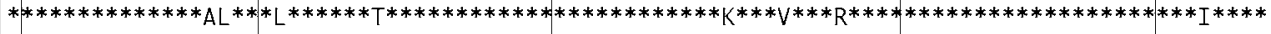 \\
\hline rGPR39 & 91 & 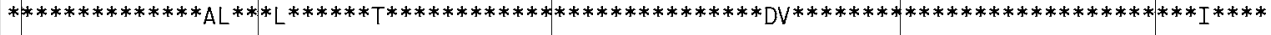 \\
\hline GPR39 & & 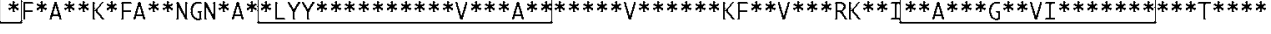 \\
\hline & & \\
\hline & 81 & VNVPSHRGLI-CNRSRTRHQEQPESSNMSICTNLSSRWTVFQSSIFSAFVVYLVVLVSVAFMCWSMMQ) \\
\hline & & $* * * * * * * * * *-* * * * \mathrm{~S}^{* * * *} \mathrm{H}^{* * * * *} \mathrm{~T}^{* * * * * * * * * * * * * * * * * * * * * * \mathrm{G} * * * * * * * *}$ \\
\hline SPR39 & 81 & 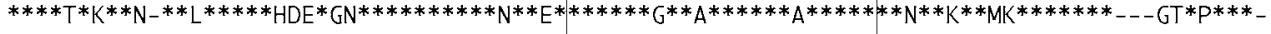 \\
\hline 239 & 81 & 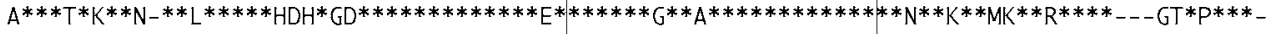 \\
\hline CGPR39 & 180 & EIIENYQ*VTA*AK*TA**HLPELKQ**T***S***K*P***A******A**II**G******* $\mathrm{R}^{* * * \mathrm{~K}} \mathrm{~K} \mathrm{~T}^{*} \mathrm{MIH} \mathrm{M}^{*} \mathrm{~K} * * \mathrm{~V} * \mathrm{VKGEP} * * * \mathrm{E} * \mathrm{Y}$ \\
\hline & & VI \\
\hline GPR39 & 266 & LRKLESQESRSARRQTIIFLELIWVTLAVCWMPNQVRRIMAAAKPKHDW \\
\hline & 66 & $* * * \mathrm{~S}^{* *} \mathrm{E}^{* * * *} \mathrm{~T} * * * * * * * * \mathrm{P}^{* * * * * * * * * *}$ \\
\hline 39 & 266 & 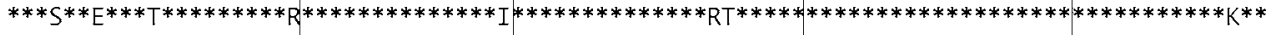 \\
\hline & 266 & 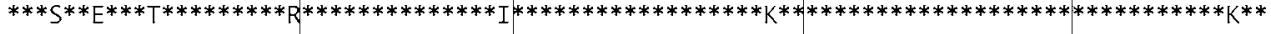 \\
\hline GPR39 & 270 & 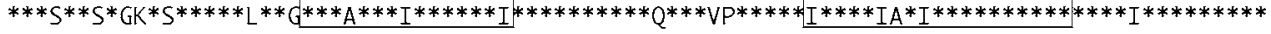 \\
\hline 39 & 56 & MDSTRSACRPLIFPASQR-S \\
\hline & 56 & 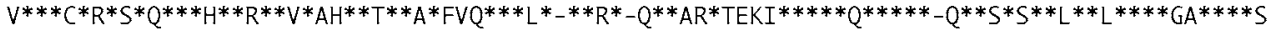 \\
\hline & 356 & 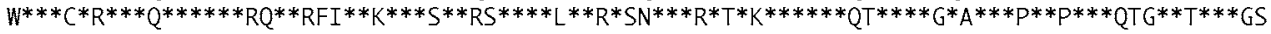 \\
\hline 39 & 356 & 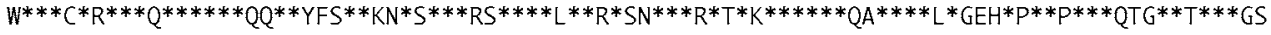 \\
\hline & 360 & 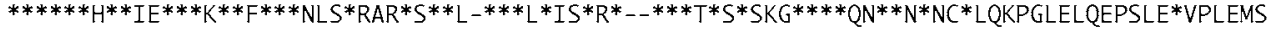 \\
\hline
\end{tabular}

$\begin{array}{lll}\text { bGPR39 } & 444 \text { ATRNGFQEH-----EV } & 454 \\ \text { hGPR39 } & 443 \text { *AE******-----** } & 453 \\ \text { mGPR39 } & 446 \mathrm{~T}^{*} \mathrm{E} * \mathrm{SL} * * \mathrm{Q}-----* * & 456 \\ \text { rGPR39 } & 446 * * \mathrm{E}^{*} \mathrm{SL} * \mathrm{Q}^{*-----* *} & 456 \\ \text { CGPR39 } & 447 \text { SKPRPDAQNGLCER** } & 462\end{array}$

Fig. 1. Alignment of the amino acid sequences of bovine, human, mouse, rat, and chicken GPR39. The amino acid sequences of bovine GPR39 are aligned with those of human (AF034633), mouse (BC085285), rat (XM_222578), and chicken (DQ768750) GPR39. The seven TM regions are boxed. Asterisks indicate amino acid residues matched to the bovine GPR39 sequence.

GPR39 gene consists of 2 exons. Recently, the human GPR39 gene was shown to have a similar exon / intron structure [3].

The predicted sequence of 454 amino acids for bovine GPR39 showed high overall homology with human (82.8\%), mouse $(82.0 \%)$ and rat (81.6\%) GPR39 and relatively low homology with chicken GPR39 (63.8\%; Fig. 1). The seven transmembrane (TM) regions were conserved in bovine
GPR39 with relatively high homology to the corresponding regions in mammalian and chicken GPR39. The two cytoplasmic loop regions between TMs I and II and between TMs III and IV (amino acid positions 57-71 and 130-154, respectively) and an extracellular loop region between TMs VI and VII (positions 302-322) were highly conserved. The cytoplasmic C-terminal region of bovine GPR39 (amino acid positions 353-454) showed relatively low homology 


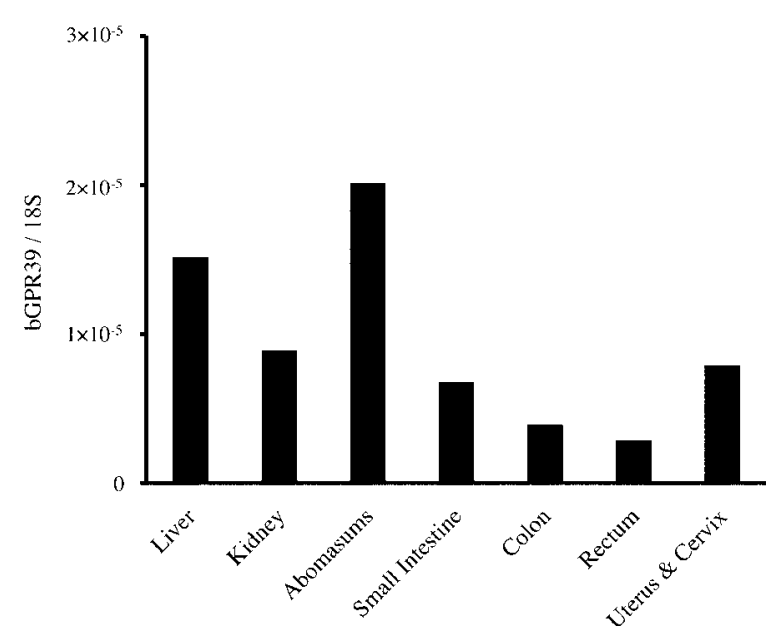

Fig. 2. Tissue distribution of bovine GPR39 mRNA. Expression levels of GPR39 mRNA in the tissues of a 2-year-old cow were determined by Q-PCR. Each value for GPR39 is normalized to that of $18 \mathrm{~S}$ ribosomal RNA.

with the corresponding region in human (65.5\%), mouse (67.0\%), rat (65.2\%) and chicken (53.3\%) GPR39. The two conserved cytoplasmic loop regions are considered to be interaction sites with $G$ protein. Mutagenesis study of human GPR39 demonstrated that $\mathrm{Zn}^{2+}$ stimulates inositol phosphate accumulation through His ${ }^{17}$, His ${ }^{19}$ and $\mathrm{Asp}^{313}$ located in the N-terminal extracellular and 3rd extracellular loop regions [17]. These three amino acid residues are conserved at the corresponding positions in bovine GPR39.

To examine the expression level of GPR39 mRNA in bovine tissues, we performed RT-PCR (real-time PCR) with a pair of sense (primer 5) and antisense (primer 6) primers. Total RNA samples from the liver, kidney, abomasums, small intestine, colon, rectum and uterus of a 2-year-old Holstein cow were purchased from BioChain Institute, Inc. (Hayward, CA, U.S.A.). Quantitative measurement was performed by establishing a linear amplification curve from serial dilutions of cDNAs for bovine GPR39 and 18S ribosomal RNA (Primers 7 and 8). As shown in Fig. 2, GPR39 mRNA was detected in all tissues, with the highest level in the abomasums, which implies the involvement of GPR39 in GI functions. In humans and rats, GPR39 mRNA is expressed in a wide range of tissues, with the highest levels in the GI tract $[21,12]$, and regression of gastric emptying activity has been observed in GPR39 deficient mice [13]. Interestingly, relatively high expression of GPR39 mRNA is observed in the bovine uterus. We recently showed that GPR39 mRNA is abundantly expressed in the chicken oviduct, including the uterus, as well as in the digestive tract [19]. These results suggest that GPR39 may play a role in peristaltic action in the reproductive tract as well as in the GI tract.

Finally, we examined the promoter activity of the 5'upstream regions of the bovine GPR39 gene in human colon carcinoma-derived CACO-2 cells. A genomic DNA fragment spanning from -2323 to $-138(+1$ : A in the initiation codon) in the upstream region of the bovine GPR39 gene was amplified by PCR using a pair of sense (primer 9) and antisense (primer 10) primers and was subcloned into the MluI and XhoI sites in the pGL3-Basic luciferase vector (Promega, Madison, WI, U.S.A.). Serial deletions were introduced into the 5'-region of the gene fragment in the pGL3 vector using a 5'-Deletion Kit (Nippon Gene, Toyama, Japan), and the positions of the 5'- end were determined by sequencing. The pGL3 vector DNAs (200 ng each) were transfected into CACO-2 cells with LipofectAMINE 2000 Reagent (Invitrogen). Four ng of pRLCMV plasmid (Promega) was co-transfected as an internal control for transfection efficiency. Forty-eight hours after transfection, luciferase activity was determined using the Dual-Glo Luciferase Assay System (Promega). The fire fly luciferase activity derived from the pGL3 vectors was normalized to the renilla luciferase activity derived from the pRL-CMV vector. Transcription factor binding sites in the

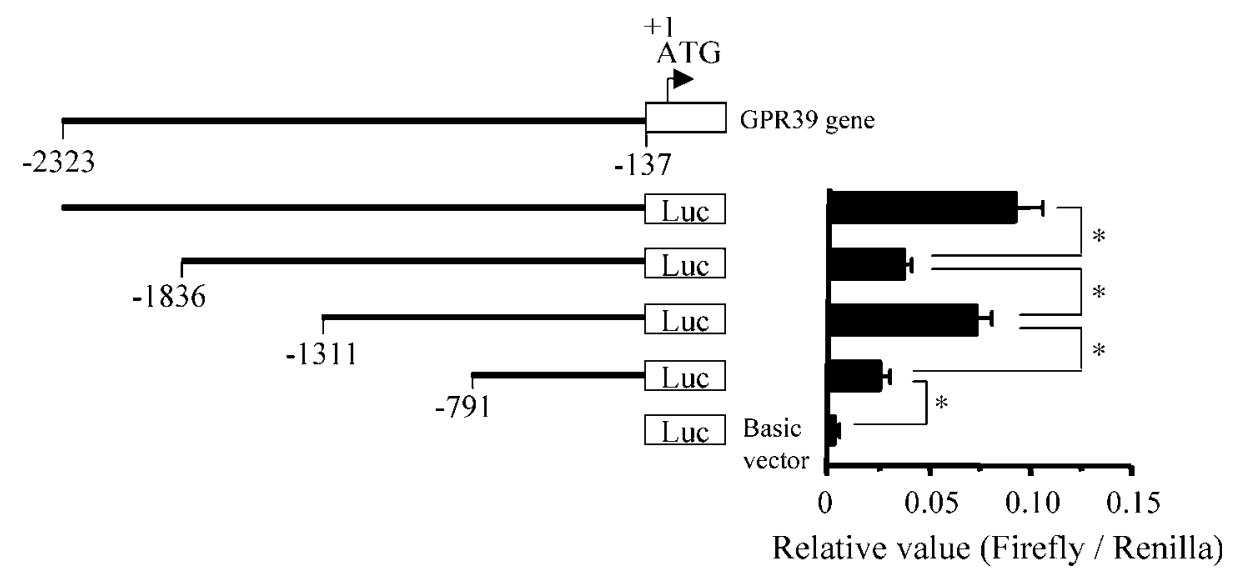

Fig. 3. Promoter activity of the 5'-flanking region of the bovine GPR39 gene. CACO-2 cells were transfected with luciferase gene constructs containing serially deleted 5'-flanking regions of the bovine GPR39 gene. Values are means \pm SEM of 4 experiments. Statistical comparisons were made using Student's $t$ tests (* $\mathrm{P}<0.05)$. 
upstream region were predicted using TFSEARCH (www.cbrc.jp/research/db/TFSEARCH.html). As shown in Fig. 3, the highest activity was observed in the region from -2323 to -138 , and the deletion from -2323 to -1836 significantly decreased the activity. Further deletion (-2323 to -1311) recovered the activity, but deletion up to -791 resulted in a significant decrease in activity compared with deletion up to -1311 . Basal promoter activity was detected in the region between -138 and -791 , which contains an SP1 site (-640) and an HNF-1 $\alpha$ site (-462); this suggests the involvement of these two transcription factors in activation of the bovine GPR39 gene. It has recently been shown that HNF-1 $\alpha$ and SP1 are involved in activation of the promoter of the human GPR39 gene in human glioblastomaderived U138 cells and human hepatocarcinoma-derived HepG2 cells. In addition to the SP1 and HNF-1 $\alpha$ sites, transcription factor elements for NF-E2 $(-515)$, Oct-1 $(-1230)$, c-Myb (-1450), NF-kappaB $(-1620,-1670)$ and Oct-1 (-2237) are present within the -2323 upstream region, the region in which significantly higher promoter activity was observed. Further analysis is required to determine the transcription factors involved in regulation of the bovine GPR39 gene.

ACKNOWLEDGEMENTS. This work was supported by a Grant-in-Aid for Young Scientists (B 20780211) and by a Project for Private Universities: Matching Fund Subsidy from the Ministry of Education, Culture, Sports, Science and Technology of Japan.

\section{REFERENCES}

1. Chartrel, N., Alvear-Perez, R., Leprince, J., Iturrioz, X., ReauxLe Goazigo, A., Audinot, V., Chomarat, P., Coge, F., Nosjean, O., Rodriguez, M., Galizzi, J.P., Boutin, J.A., Vaudry, H. and Llorens-Cortes, C. 2007. Comment on "Obestatin, a peptide encoded by the ghrelin gene, opposes ghrelin's effects on food intake". Science. 315: 766.

2. Dickin, J.C., Thue, T.D. and Buchanan, F.C. 2004. An alternative splice site in ghrelin is missing in ruminants. Anim. Genet. 35: 411-412.

3. Egerod, K.L., Holst, B., Petersen, P.S., Hansen, J.B., Mulder, J., Hokfelt, T. and Schwartz, T.W. 2007. GPR39 splice variants versus antisense gene LYPD1: expression and regulation in gastrointestinal tract, endocrine pancreas, liver, and white adipose tissue. Mol. Endocrinol. 21: 1685-1698.

4. Feighner, S.D., Tan, C.P., McKee, K.K., Palyha, O.C., Hreniuk, D.L., Pong, S.S., Austin, C.P., Figueroa, D., MacNeil, D., Cascieri, M.A., Nargund, R., Bakshi, R., Abramovitz, M., Stocco, R., Kargman, S., O'Neill, G., Van Der Ploeg, L.H., Evans, J., Patchett, A.A., Smith, R.G. and Howard, A.D. 1999. Receptor for motilin identified in the human gastrointestinal system. Science. 25: 2184-2188.

5. Gourcerol, G., St-Pierre, D.H. and Taché, Y. 2007. Lack of obestatin effects on food intake: should obestatin be renamed ghrelin-associated peptide (GAP)? Regul. Pept. 141: 1-7.

6. Holst, B., Egerod, K.L., Schild, E., Vickers, S.P., Cheetham, S., Gerlach, L.O., Storjohann, L., Stidsen, C.E., Jones, R., BeckSickinger, A.G. and Schwartz, T.W. 2007. GPR39 signaling is stimulated by zinc ions but not by obestatin. Endocrinology $\mathbf{4 8}$ :
13-20.

7. Holst, B., Holliday, N.D., Bach, A., Elling, C.E., Cox, H.M. and Schwartz, T.W. 2004. Common structural basis for constitutive activity of the ghrelin receptor family. J. Biol. Chem. 79: 5380653817.

8. Huang, Z., Depoortere, I., De Clercq, P. and Peeters, T. 1999. Sequence and characterization of DNA encoding the motilin precursor from chicken, dog, cow and horse. Evidence of mosaic evolution in prepromotilin. Gene. 240: 217-226.

9. Kitazawa, T., De Smet, B., Verbeke, K., Depoortere, I. and Peeters, T.L. 2005. Gastric motor effects of peptide and nonpeptide ghrelin agonists in mice in vivo and in vitro. Gut. 54: 1078-1084.

10. Lauwers, E., Landuyt, B., Arckens, L., Schoofs, L. and Luyten, W. 2006. Obestatin does not activate orphan G protein-coupled receptor GPR39. Biochem. Biophys. Res. Commun. 351: 21-25.

11. Masuda, Y., Tanaka, T., Inomata, N., Ohnuma, N., Tanaka, S., Itoh, Z., Hosoda, H., Kojima, M. and Kangawa, K. 2000. Ghrelin stimulates gastric acid secretion and motility in rats. Biochem. Biophys. Res. Commun. 276: 905-908.

12. McKee, K.K., Tan, C.P., Palyha, O.C., Liu, J., Feighner, S.D., Hreniuk, D.L., Smith, R.G., Howard, A.D. and Van der Ploeg, L.H. 1997. Cloning and characterization of two human G protein-coupled receptor genes (GPR38 and GPR39) related to the growth hormone secretagogue and neurotensin receptors. Genomics. 46: 426-434.

13. Moechars, D., Depoortere, I., Moreaux, B., de Smet, B., Goris, I., Hoskens, L., Daneels, G., Kass, S., Ver Donck, L., Peeters, T. and Coulie, B. 2006. Altered gastrointestinal and metabolic function in the GPR39-obestatin receptor-knockout mouse. Gastroenterology. 131: 1131-1141.

14. Nogueiras, R., Pfluger, P., Tovar, S., Arnold, M., Mitchell, S., Morris, A., Perez-Tilve, D., Vazquez, M.J., Wiedmer, P., Castaneda, T.R., DiMarchi, R., Tschop, M., Schurmann, A., Joost, H.G., Williams, L.M., Langhans, W. and Dieguez, C. 2007. Effects of obestatin on energy balance and growth hormone secretion in rodents. Endocrinology. 148: 21-26.

15. Poitras, P., Edited by Walsh, J.H. and Dockray, G.J. 1994. Motilin. pp. 261-304. In: Gut Peptides:Biochemistry and Physiology. New York, Ravin.

16. Seoane, L.M., Al-Massadi, O., Pazos, Y., Pagotto, U. and Casanueva, F.F. 2006. Central obestatin administration does not modify either spontaneous or ghrelin-induced food intake in rats. J. Endocrinol. Invest. 29: RC13-15.

17. Storjohann, L., Holst, B. and Schwartz, T.W. 2008. Molecular mechanism of $\mathrm{Zn}^{2+}$ agonism in the extracellular domain of GPR39. FEBS Lett. 582: 2583-2588.

18. Tack, J., Depoortere, I., Bisschops, R., Delporte, C., Coulie, B., Meulemans, A., Janssens, J. and Peeters, T. 2006. Influence of ghrelin on interdigestive gastrointestinal motility in humans. Gut. 55: 327-333.

19. Yamamoto, I., Numao, M., Sakaguchi, Y., Tsushima, N. and Tanaka, M. 2007. Molecular characterization of sequence and expression of chicken GPR39. Gen Comp. Endocrinol. 151: 128-134.

20. Yasuda, S., Miyazaki, T., Munechika, K., Yamashita, M., Ikeda, Y. and Kamizono, A. 2008. Isolation of $\mathrm{Zn}^{2+}$ as an endogenous agonist of GPR39 from fetal bovine serum. J. Recept. Signal Transduct. Res. 27: 235-246.

21. Zhang, J.V., Ren, P.G., Avsian-Kretchmer, O.C., Luo, W., Rauch, R., Klein, C. and Hsueh, A.J. 2005. Obestatin, a peptide encoded by the ghrelin gene, opposes ghrelin's effects on food intake. Science. 310: 996-999. 